\title{
THE EFFECT OF GUIDED DISCOVERY LEARNING MODEL ON STUDENT'S ACHIEVEMENT AT CHARACTERISTICS OF WAVE TOPIC IN SMA N 1 MEDAN CLASS XI ACADEMIC YEAR 2014/2015
}

\author{
Yohana Glorya Tobing and Alkhafi Maas Siregar \\ Jurusan Fisika FMIPA Universitas Negeri Medan \\ Jalan Willem Iskandar Pasar V Medan, Sumatera Utara \\ glo.tobink@gmail.com
}

\begin{abstract}
The aim of this research was to find the effect of guided discovery learning model on student's achievement at characteristics of wave topic in SMA N 1 Medan class XI academic year 2014/2015. The research method was quasi-experiment. The populations were all $2^{\text {nd }}$ grade students odd semester consist of 13 classes in SMA N 1 Medan. The samples of this research conduct two classes and consist of 37 students from experiment class and control class defined by cluster random sampling. The results that were obtained: post-test mean value of the experiment class was 75.94 and 75.02 for control class. Standard deviation for two classes was 14.94 and 12.48 . Normality of the test result from the both samples was normal and homogeneous. So, there was the significant effect of using guided discovery learning model. It can conclude that studying with guided discovery learning model was higher than direct instructional learning model.
\end{abstract}

Key word: guided discovery learning, student's learning achievement, learning model, physics

\section{BACKGROUND}

Education is learning about knowledge, skills, and habits of a group of people passed down from one generation to the next through teaching, training, or research . Education is often the case under the guidance of others, but also allows a self-taught. Education is not only an obligation, beyond that education is a necessity where humans will be developed with the education. The purpose of education itself vary, depending on each individual personally saw education itself, education can improve the economic status, help to get the comfortable job, some are looking at education means transportation to bring it to the level it all.

School is one of the educational system that serves to help improve the quality of human resources. From the nation's education children receive in school, will be able to change the mindset and creativity to create a welfare state with a good and growing economy. School is part of the design that made by the Government in the field of education with the operational foundation is the curriculum. This curriculum goals of education is the nation expected to be made by systematically to achieve the nation of Indonesia.

Graduate competencies described in three dimensions: (a) attitudes, (b) skills and (c) knowledge, accordance with the Peraturan Menteri Pendidikan dan Kebudayaan No.53 Tahun 2013 on Competency Standards for Primary and Secondary Education. Attitude is part of the affective domain, a domain of psychomotor skills, and domain knowledge. So the order of taxonomy education curriculum in 2013, 
is the main attitudes, followed by skills, knowledge domain as last. The attitude should be promoted first, continue to skills, and the last is the knowledge. In the process of achieving the learning objectives of the curriculum should be done. Whether it in the process of learning and learning achievements.

Physics is one of the compulsory subjects in high school (SMA) that must be completed. Many students who complain are not too fond of physics because they consider physics lesson is difficult. Once the researchers conducted observations back at SMA Negeri 1 Medan, researchers can conclude that there are problems that occur during the process of learning physics, both from teachers, students and schools. A total of $11 \%$ very fond of physics, 54\% liked the physics lesson and $35 \%$ have normal response in physics. Many of them consider the lessons of physics are just a compulsory lessons. They learned just to complete their learning process. Observations from SMA Negeri 1 Medan also showed that as many as $53 \%$ of students happy working on a way of discussion, $17.33 \%$ happy if working independently in the process of matter, $17.33 \%$ felt indifferent and sometimes lazy to do and $12.34 \%$ happy if the students about the given an easy matter. From the data is known that the daily examination results at SMA Negeri 1 Medan 57\% have not crossed the line of standard minimum competency (KKM) for sciences subject.

In a typical college classroom, this presents as a teacher lecturing at the front of the room while students feverishly take notes. However, it is probably more likely that most instructors do not solely teach in this passive fashion but also have engaging or interactive classroom moments or situations. Perhaps this is because many recent studies (Michel, et al., 2009) suggest that the passive method may not be the most effective way for students to learn. Rather, current research advocates for teaching techniques that encourage students to actively engage in the material because classroom engagement has been found to promote deeper levels of thinking and better facilitate encoding, storage, and retrieval than traditional lecture. Consequently, it is likely that most instructors attempt to incorporate techniques that involve the students and get students thinking about and applying the material (see Michel, et al., 2009 for a review). These techniques can range from demonstrations, to discussions, to in-class activities (Hackathorn, Jana., Salomon, E..D., Blankmeyer, 2011). Simply put, traditional ideas of lecture have developed a bad reputation, and some may be ready to banish them from their teaching repertoire.

Factors that led to the above due to lack of students' understanding of physics concepts. Lack of students' understanding of the concepts of physics can be addressed by changing the learning models. The model of teaching according to (Joyce, 2004; Arends, 2012) is a description of a learning environment that describes the planning of curriculum, courses, design lesson units and learning, learning equipment, work books, multimedia programs, and learning support through the computer. The model of teaching not only has the meaning of a descriptive and immediacy, but also means a prospective and oriented to time future (Arends, 2010). Learning objectives are usually directed at one of the area from the taxonomy. There are, cognitive, affective and psychomotor. This cognitive region consists of 6 (six) in successive hierarchical levels namely: (1) remembering; (2) understanding; applying; (4) analyzing; (5) evaluating; and (6) creating (Krathwoll, 2002).

Guided Discovery learning model of learning can improve learning outcomes for students in this learning model can better understand what is being learned. In applying the learning model Guided Discovery learning teachers act as mentors to provide the opportunity for students to learn actively, as the opinion of the teacher should be able to guide and direct the learning activities of students in accordance 
with the purpose (Sardiman, 2009). Such conditions would like to change the teaching and learning activities are teacheroriented to student-oriented (Hosnan, 2014).

\section{RESEARCH METHODOLOGY}

This research has been done at Senior High School (SMA Negeri) 1 Medan. The population of this research are all of the students in class XI SMA Negeri 1 Medan that consist of thirteen classes with the students average is 37 students in every class. The sample is choosen by cluster random sampling. The sample is divided into two classes consisting of one class as experimental class and the other class as control class.

This research is involved two different treatments for the experimental class and the control class, where the two classes are treated differently. The experimental class treated with guided discovery learning model and the control class treated with direct instructional learning model.

To determine the students understanding of the concept, researcher use test on both classes before and after treatment, which are called pretest and posttest. The design of the research is as follows:

Table 1. Design of Research

\begin{tabular}{|l|l|l|l|}
\hline Class & Pretest & Treatment & Posttest \\
\hline Experiment & $\mathrm{X}_{1}$ & $\mathrm{~T}$ & $\mathrm{X}_{2}$ \\
\hline Control & $\mathrm{X}_{1}$ & $\mathrm{O}$ & $\mathrm{X}_{2}$ \\
\hline
\end{tabular}

Description :

$\mathrm{X}_{1}=$ Pretest

$\mathrm{X}_{2}=$ Posttest

$\mathrm{T}=$ Applying Guided Discovery Learning Model

$\mathrm{O}=$ Applying direct instructional learning model

The selection of data is carried out to observe whether the samples come from normal distribution population or not. The test used is Liliefors test and Homogeneity test, to know the homogenity of both samples used formula as follows (Sudjana, 2005) :

Description:

$=$ Biggest Variance Data

$=$ Smallest Variance Data

The test criteria are received Ho: the data come from a homogeneous population if $\mathrm{F}$ count $<\mathrm{F}$ table, where the $\mathrm{F}$ table obtained from the distribution list $F$ with $\alpha=0.05$. Here $\alpha$ is a real level for testing.

Hypothesis test use t-test with formula (Sudjana, 2005) :

$\mathrm{S}$ is combination of standard deviation can be calculated with formula :

Where :

$=$ Average value in experimental class.

$=$ Average value in control class.

$=$ Total of sample in experimental class.

$=$ Total of sample in control class. = Variance

$=$ Variance in experimental class

$=$ Variance in control class

$\mathrm{t}=\mathrm{t}$ distribution

Testing Criteria : $\mathrm{H}_{\mathrm{o}}$ accept if $\mathrm{t}_{\text {calculate }}<\mathrm{t}{ }_{(1-)}$ where $t_{(1-)}$ get from distribution table $t$ with independent degree $(\mathrm{dk})=\mathrm{n}_{1}+\mathrm{n}_{2}-2$ and the probability (1-) with $=0,05$ for another value of $\mathrm{t} \mathrm{H}_{\mathrm{o}}$ not accept, so Guided Discovery Learning Model has effect to the student's achievement in learning physics.

\section{RESULT OF RESEARCH}

This research conducted quasi experimental research that aims to determine whether there is significant difference of students' learning outcomes using Guided Discovery learning model and direct instructional model in Characteristics of wave topic at class XI SMA N 1 Medan.

Based from research data, the average value, standard deviation and variance in control and experiment class is:

Table 2. The Average, Standard Deviation and Variance in Experiment Class

\begin{tabular}{|l|l|l|}
\hline Result & Pretest & Posttest \\
\hline $\mathrm{Av}$ & 42.27 & 75.94 \\
\hline $\mathrm{Sd}$ & 13.81 & 14.94 \\
\hline
\end{tabular}




\begin{tabular}{|l|l|l|}
\hline Var & 190.75 & 223.44 \\
\hline
\end{tabular}

The achievement of cognitive test shows average score of pre-test and posttest in experiment class was higher than control class.

Table 3. The Average, Standard Deviation and Variance in Control Class

\begin{tabular}{|l|l|l|}
\hline Result & Pretest & Posttest \\
\hline $\mathrm{Av}$ & 38.70 & 75.02 \\
\hline $\mathrm{Sd}$ & 12.48 & 17.49 \\
\hline Var & 155.77 & 306.02 \\
\hline
\end{tabular}

Description:

Av : Average

Sd : Standard Deviation

Var : Variance

Figure 1. The average of Pretest and Posttest in Experiment Class

The average of post-test in experimental class is greater than the pretest caused by the treatment by using guided discovery learning model in experiment class.

In control class, the post-test was greater caused by the direct instructional learning model that have an effect to student's learning achievement in control class. Here the figure of average in pre-test and post-test in control class:

Figure 2. The average of Pretest and Posttest in Control Class

The results of hypothesis testing one tail on the post-test with $\alpha=0.05$ obtained the score $t_{\text {count }}=3.78$ and $t_{\text {table }}=1.668$. By comparing $t_{\text {count }}$ and $t_{\text {table }}$ obtained $t_{\text {count }}>t_{\text {table }}$ it's $3.78>1.668$ so Ha accepted. It can be conclude that guided discovery learning model has effect on student's learning achievement in characteristics of wave topic at class XI SMA N 1 Medan academic year 2014/2015.
The achievement of cognitive test shows average score of pretest in the experimental class is 42.27 with deviation standard of 13.81 and the average posttest value is 75.94 with deviation standard of 14.94. While the values obtained in the control class average pretest is 38.70 with deviation standard of 12.48 and the average posttest value is 75.02 with deviation standard of 17.49. From the data, average posttest value in experimental class is greater than control class. The increasing of posttest value is caused by the treatment given to the students. In experimental class given treatment using guided discovery learning model and control class given the treatment using direct instructional.

The observation result in student's activity showed the activeness of students during the learning greatly affects the value of learning achievement. The activity of student can be seen more specify from doing worksheet in the experimental class and in control class, the activity of students can be observed when the researcher doing the teaching activity and giving problems. When the students are active in learning activity, the learning outcomes become higher. There is different activity of students' in experimental class and control class. The average value of students' activity in experimental class is higher than control class. It also the reason that the average value of posttest value in experimental class is greater than control class.

The results in Cognitive and Activity of students showed that there was effect of Guided Discovery Learning Model on the student's achievement in characteristics of wave topic in class XI SMA N 1 Medan Academic Year 2014/2015.

Observation result in student activity showed that students' attitude in experiment and control class is in good category, but average value of student activity in experiment class more active than control class. 
Implementation of Guided Discovery learning model in experiment class make the students become active, because Guided Discovery Learning Model make student more creative and understand about physics phenomena. Guided Discovery Learning Model developed good ethic of student, like creative, discipline, and responsibility so the affective of students is good. The student achievement in cognitive of experiment class is also high.

Good achievement of student in experiment class is due to better teaching and learning process using Guided Discovery Learning Model that carried the students directly in the learning process to find a concept or principle. With these techniques, the students find themselves left or experiencing a mental process themselves, teacher only guide and provide instruction. Method of guided discovery learning as a theory of learning can be defined as learning that occurs when students are not presented with a lesson in its final form, but is expected to organize themselves. They found the concept of physics from experiment or observation by themselves and make students more interesting to learn physics, so they also remember it for long time and make students understand about the concepts.

In hypothesis test showed that there is significant difference of student's achievement in experiment and control class. The student's achievement is better in experiment class. So, can be concluded that Guided Discovery Learning Model have effect to student's achievement in fluid topic in class XI SMA N 1 Medan Academic Year 2014/2015.

The Guided Discovery Learning Model has been researched by Feggi (2014), Sri (2012), and the result of this research is suitable with their research result, where in their result the student's achievement taught by Guided Discovery learning model is better than direct instructional learning.
Although the Guided Discovery learning model could improve learning achievement, but during in teaching and learning process the Guided Discovery learning model has the disadvantage, due to the weakness of researcher, the activity don't give the big contribution to the increasing of student's posttest value, so for next researcher suggest to make a better descriptor to the implementation stages according to Guided Discovery learning model.

\section{CONCLUSION}

Based on the result of research data, it can be concluded that: Student's achievement in experiment class is greater than student's achievement in control class. This reveal that Guided Discovery learning model has effect on student's achievement in learning physics at SMA Negeri 1 Medan.

\section{SUGGESTION}

According to the data of student's achievement and the experience of research when applying the Guided Discovery learning model in class, so the researcher gives suggestion that for the next researcher who wants to do research using Guided Discovery learning model, pay more attention to implementation stages according to Guided Discovery learning activities and develop a better descriptor.

\section{REFERENCES}

Arends, R.I., A. 2010. Teaching for Student Learning. New York: Routlegde

Arends, R.I., A. 2012. Learning to Teach (Ninth Edition). New York: Mc Graw Hill

Hackathorn, Jana., Salomon, E.D., Blankmeyer, K.L. 2011. Learning by Doing: An Empirical Study of Active Teaching Techniques. Journal of Effective Teaching, 4054 
Hosnan. 2014. Pendekatan Saintifik dan Kontekstual dalam Pembelajaran Abad 21. Jakarta: Ghalia Indonesia

Joyce, Bruce. 2004. Models of Teaching (fifth edition). New Jersey: PrenticeHall International, Inc

Krathwol. 2002. Revising Bloom's Taxonomy. The H.W Company

Michel, N., Cater III, J. J., \& Varela, O. (2009). Active versus passive teaching styles: An empirical study of student outcomes. Human Resource Development Quarterly, 20(4), 397-418.

Purba, Sri., 2012. Pengaruh Strategi Pembelajaran Discovery dan Sikap Inovatif terhadap hasil belajar Biollogi kelas X SMA Budi Murni 2
Medan. Master Theses of Universitas Negeri Medan

Sardiman A.M. 2009, Interaksi dan Motivasi Belajar Mengajar, Rajawali Pers, Jakarta.

Bandung: Tarsito.

Sudjana, N. 2010. Penilaian Hasil Proses Belajar Mengajar. Bandung: PT Remaja Rosdakarya

Yuandini, Feggy., 2014. The Effect of Guided Discovery Learning Model On Student's Learning Outcomes Of Static Fluid In Class XI SMA Negeri 1 Berastagi A.Y. 2013/2014. Undergraduate Theses of Universitas Negeri Medan 
